\title{
SOSIAALIPOLITIIKAN JÄRJESTÄMINEN MUUTTUVASSA HYVINVOINTIVALTIOSSA: TARKASTELUSSA TULOSPERUSTEINEN RAHOITUSSOPIMUS
}

Pekka Pennanen: VTM, väitöskirjatutkija, Helsingin yliopisto

Jyri Liukko: VTT, erikoistutkija, Eläketurvakeskus

pek.ka.m.pennanen@gmail.com;jyri.liuk.ko@etk.ji

Janus vol. 27 (2) 2019, $x x x-x x x$

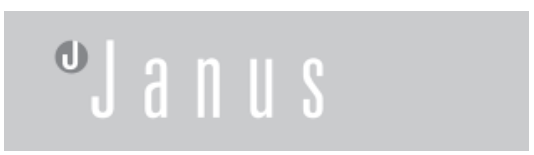

Tiivistelmä

Artikkelissa tutkimme vaikuttavuusinvestoimista ja sen sovellusta, tulosperusteista rahoitussopimusta, uudenlaisina sosiaalipolitiikan toteutusmekanismeina. Vaikuttavuusinvestoimisessa hyvinvointia tavoitellaan yksityisen ja julkisen rahoitusjärjestelyn yhteistyöllä. Kysymme, miten vaikuttavuusinvestoimista ja tulosperusteista rahoitussopimusta perustellaan ja minkälaisia ongelmia siinä nähdään. Aineisto koostuu vaikuttavuusinvestoimisen parissa työskentelevien asiantuntijoiden haastatteluista. Kansainvälisen keskustelun on esitetty nojaavan kolmeen narratiiviin. Suomalaisessa keskustelussa ilmenee osittain samoja teemoja kuin kansainvälisessä kirjallisuudessa. Suomessa mallia perustellaan etenkin heikolla taloustilanteella. Muita perusteluita ovat mallin mahdollistamat paremmat palvelut ja eri sektoreiden yhteistyö. Mallissa nähdään myös riskejä. Prosessina vaikuttavuusinvestoiminen on jatkoa markkinoitumiselle ja yksityisen palvelutuotannon kasvulle. Ehdotamme artikkelissa myös uutta käännöstä tulosperusteiselle rahoitussopimukselle.

\section{JOHDANTO}

Pohjoismaisessa hyvinvointivaltiossa sosiaalipolitiikka on perinteisesti kuulunut julkiselle sektorille, kun esimerkiksi anglosaksisessa hyvinvointimallissa yksityisten toimijoiden merkitys on ollut suurempi (Kosonen 1998; Kiander \& Lönnqvist 2002; Saari 2013). Suomalaisessa sosiaalipolitiikassa tapahtui kuitenkin selkeä muutos 1980- ja 1990-luvuilla. Sääntelyä, suunnittelua ja holhousta suosinut retoriikka vaihtui korostamaan kilpailua ja tehokkuutta. Julkishallintoa tehostettiin ja käyttöön otettiin uuden julkisjohtamisen oppeja yksityiseltä sektorilta ja yritysmaailmasta. (Alasuutari 2004; Heiskala \& Luhtakallio 2006, 7-11; Hiilamo ym. 2012, 20.) Käännekohta hyvinvointipolitii- kassa oli 1990-luvun lama,jonka myötä Suomessa alettiin etsiä uusia tapoja sosiaali- ja terveyspalveluiden tuottamiseen ja järjestämiseen (Kosonen 1998, 346-392; Julkunen 2001; Alavaikko 2007, 50).

Sosiaaliturvajärjestelmä selviytyi lamasta melko toimintakykyisenä. Tosin ongelmaksi jäi pitkäaikaistyöttömyys ja joidenkin ihmisryhmien syventynyt köyhyys. (Heikkilä 1997; Kiander 2001, 5; Ritakallio 2007.) Laman jälkeen ja 2000-luvulla on kiinnitetty huomiota julkisten palveluiden tehokkuuteen ja tuottavuuteen (Laine \& Valtonen 2004; Kananen 2008). Ratkaisukeinoiksi on esitetty palveluiden yksityistämistä, ulkoistamista ja markkinamekanismien soveltamista (Alasuutari 2004; Niemelä 
2008; Laatu 2009; Junnila \& Fredriksson 2012). Muutoksen myötä sosiaalipolitiikka etsii suuntaansa (Vaarama 2011, 24). Yhdeksi hyvinvointipolitiikan haasteiden ratkaisuksi on viime vuosina tarjottu vaikuttavuusinvestoimista. Sen tavoitteena on kanavoida uudenlaisella tavalla yksityistä pääomaa hyvinvointia tuottaviin hankkeisiin.

Artikkelissa tutkimme vaikuttavuusinvestoimista (Impact Investing) ja sen yhtä toteutusmuotoa, tulosperusteista rahoitussopimusta (Social Impact Bond), josta käytämme myös lyhennettä SIB. Siinä yksityiset sijoittajat investoivat julkisen sektorin vastuulle kuuluvaan hyvinvointipalveluun ja kantavat rahoitusriskin. Määriteltyjen tavoitteiden täyttyessä sijoittajalle maksetaan takaisin sijoitettu pääoma ja lisäksi sovittu tuotto-osuus. Jos SIB-hankkeelle määritellyt tulostavoitteet eivät toteudu, rahoitusriskin kantaa sijoittaja. (BuggLevine \& Emerson 2011; Liebman \& Sellman 2013; de la Peña 2015; Hilli ym. 2015 , 6.) Vaikuttavuusinvestoimisen instrumentit ovat lainoja, osakesijoituksia, tulosperusteisia rahoitussopimuksia tai lainan variaatioita (Männistö 2016, 18-22). Tutkimuskohteenamme on SIB, koska sitä sovelletaan suomalaisissa hankkeissa (Hallituksen puoliväliriihi 2017; Työ- ja elinkeinoministeriö 2017).

Artikkelissa on kaksi tutkimuskysymystä. Kysymme, miten vaikuttavuusinvestoimista ja SIB-mallia perustellaan Suomessa. Toiseksi tutkimme, missä määrin kansainvälisessä kirjallisuudessa esiintyvät narratiivit ilmenevät vaikuttavuusinvestoimista koskevassa suomalaisessa keskustelussa. Kysymys vastaa osaltaan siihen, mikä on vaikuttavuusinvestoi- misen suhde sosiaalipolitiikan muutokseen, jossa painottuu kilpailukyky, yksityistäminen ja tehokkuus (ks. Julkunen 2001 \& 2006; Alasuutari 2004; Mänttäri-van der Kuip 2013). Tarkastelemme suuntaansa etsivää sosiaalipolitiikkaa muuttuvassa maailmassa (esim. Forma ym. 2007; Palola \& Karjalainen 2011; Van Gerven 2012). Tutkimusaihe liittyy uudenlaiseen sosiaalipolitiikkaan, jossa ratkaisuja haetaan yhä enemmän yksityiseltä sektorilta ja markkinoilta. Aihe liittyy palvelujärjestelmän kestävyyteen ja sosiaalipolitiikan toteutustapoihin (ks. Koskiaho 2014). Sitä ei ole Suomessa juuri tutkittu, ja kansainvälistäkin tutkimusta on tehty niukasti (Fraser ym. 2016, 3-4).

Artikkeli on jatkoa uudesta julkisjohtamisesta, yksityistämisestä, markkinoitumisesta ja sosiaalipolitiikan suunnasta käydylle keskustelulle (Ferlie ym. 1996; Powell \& Hewitt 2002; Alasuutari 2004; Kovalainen 2004; Den Heyer 2011; Yliaska 2014). Lähestymme artikkelissa vaikuttavuusinvestoimista edellä mainittujen tapahtumien jatkumona. Tutkimusaihe pakenee vallitsevia jaotteluita, koska SIB-hankkeet ovat tiukassa julkisessa kontrollissa. Samalla ne kuitenkin soveltavat markkinalogiikkaa ja yksityisiä toimintamalleja vielä voimakkaammin kuin monet aiemmat uuden julkisjohtamisen käytännöt.

\section{Tulosperusteinen}

\section{RAHOITUSSOPIMUS KÄYTÄNNÖSSÄ}

Idean tulosperusteisesta rahoitussopimuksesta esitti taloustieteilijä Ronnie Horesh vuonna 1988. Hänen mallissaan rahoitusinstrumentin nimi oli Social Policy Bond eli sosiaalipoliittinen 
velkakirja, jonka voi lunastaa kiinteästä hinnasta sosiaalisen tavoitteen täytyttyä. (Horesh 1988, 266-280; Horesh 2000, 39-42.) SIB-malli on eräs vaikuttavuusinvestoimisen instrumentti. Vaikuttavuusinvestoiminen perustuu yhdysvaltalaisen Rockefeller Foundationin vuosina 2007-2008 tekemään tutkimus- ja kehitystyöhön (Harji \& Jackson 2012).

SIB-mallissa palvelun tilaaja, esimerkiksi kunta, valitsee vapaaehtoisen kohderyhmän, jonka asemaa pyritään parantamaan esimerkiksi sairauspoissaoloja vähentämällä. Sitten rakennetaan projektin onnistumista tarkastelevat mittarit. Hankkeissa voidaan käyttää erilaisia vertailuasetelmia, joiden avulla vaikuttavuutta mitataan (Työ- ja elinkeinoministeriö 2016). Esimerkissä ne liittyvät sairauspoissaolojen vähentymisestä saatuihin säästöihin. Tämän jälkeen kilpailutetaan hankehallinnoija, joka on yksityinen yritys. Se rakentaa SIB-rahaston, etsii palveluntarjoajat ja sijoittajat. Sijoittajat voivat olla erilaisia rahoitusinstituutioita tai muita yksityisiä tahoja. Sijoituksilla maksetaan palveluntarjoajien kustannukset. Lopuksi itsenäiset arvioijat evaluoivat hankkeen. Tavoitteiden toteutuessa hankehallinnoija palauttaa sijoitetun pääoman ja maksaa voiton sijoittajille. Tuotto-odotus SIB-hankkeissa on sopimuskohtainen. Julkinen sektori ostaa vain tuloksia. (ks. Liebmann 2011, 11-13; Nicholls \& Tomkinson 2013, 3-6; Männistö 2016; Fraser ym. 2016, 1-2.) Hankkeessa ei välttämättä tarvita julkista rahoitusta, jos tavoitteet eivät toteudu.

Taloudellisten näkökulmien lisäksi SIB tavoittelee sosiaalista hyvää, joten mallissa yhteiskuntapoliittiset tavoitteet yh- distyvät sijoittamiseen (Bugg-Levine \& Emerson 2011; Mulgan ym. 2011, 4-8). Hankkeissa on usein mukana yhteiskunnallisia yrityksiä. Ne on perustettu tietyn yhteiskunnallisen ongelman ratkaisemiseksi ja käyttävät suurimman osan voitoistaan valitun ongelman ratkaisemiseen (ks. Mäki 2012). Näin ollen SIB yhdistää liiketalouden sosiaalisiin näkökulmiin.

Ensimmäisessä Yhdysvalloissa toteutetussa SIB-hankkeessa Rikers Islandin vankilan 16-18-vuotiaille nuorisovangeille tarjottiin terapiapalveluita. Malli ei ollut teknisesti SIB, vaan lainajärjestely, jonka tavoitteena oli tuottaa sosiaalista hyvää. Sitä kutsutaan silti SIBmalliksi. (Olson \& Phillips 2013, 97.) Englantilaisen Peterboroughin vankilan SIB-projektissa pyrittiin laskemaan uusintarikollisuutta tarjoamalla vangeille vapautumisenjälkeistä apua asunnon hankkimiseen ja päihdekuntoutukseen. Vankien uusintatuomiot laskivat 8,4\% kansalliseen keskiarvoon nähden, mutta tulos ei täyttänyt sopimuksen odotusarvoa, joten tulosperusteisia maksuja ei maksettu. (Nicholls \& Tomkinson 2013; Jolliffe \& Hadderman 2014, 3, 27.) Suomalaisista hankkeista esillä ovat olleet maahanmuuttajien työllistymisedellytyksiä parantava SIB-hanke ja työhyvinvoinnin kehittämiseen tähtäävä SIB-hanke (Pyykkö \& Keltanen 2016; Työ- ja elinkeinoministeriö 2017).

\section{KOLME NARRATIIVIA TULOSPERUSTEISESTA} RAHOITUSSOPIMUKSESTA

Suurin osa tulosperusteista rahoitussopimusta käsittelevästä kirjallisuudesta on 2010-luvulta. Aiheesta on vähän akateemista tutkimusta, ja valtaosa 
kirjallisuudesta koostuu hallintoon ja kehittämistyöhön liittyvistä teksteistä. Aihetta tarkastelevasta kansainvälisestä kirjallisuudesta on löydettävissä muutamia yleisiä lähestymistapoja. Fraser ym. ovat vuonna 2016 julkaistussa artikkelissaan käyneet systemaattisesti läpi SIB-mallia käsittelevää akateemista ja muuta kirjallisuutta. He nostavat esiin kolme narratiivia, joista ilmenevät aiheeseen liittyvät teoreettiset ja käytännölliset lähestymiskulmat (Fraser ym. 2016).

Ensimmäinen narratiivi on julkisen sektorin uudistamisnarratiivi, jossa SIB nähdään mahdollisuutena julkisten hyvinvointipalveluiden uudenlaiseen järjestämiseen. Siinä julkisella sektorilla on ongelmia palveluiden toteuttamisessa ja suunnittelussa, joita nykykäytännöt eivät ratkaise. Siksi julkiselle sektorille täytyy tuoda yksityisen sektorin kannusteita ja johtamisjärjestelmiä. (Liebman 2011; Mulgan ym. 2011; HM Government 2011 \& 2013.) Narratiivissa SIB voi tuoda julkiselle sektorille yksityisen sektorin kilpailuelementtejä ja tuloksellisuusmittareita. Narratiivi korostaa rahoitusriskin siirtymistä sijoittajille. SIB-mallia perustellaan kustannussäästöillä, joilla maksetaan sijoittajien tuottoa.

Toinen narratiivi on yksityisten toimijoiden näkökulmaa korostava yksityisen rahoitussektorin uudistamisnarratiivi. Narratiivissa korostuu se, kuinka yksityisen ja julkisen sektorin arvoja yhdistämällä yksityisille toimijoille tarjoutuu mahdollisuuksia liiketoimintaan sosiaalista hyvää tavoittelevan yhteiskunnallisen yrittäjyyden avulla (Social Investment Task Force 2010; Cohen 2011; Liebman 2011; Nicholls \& Mur- dock 2012; Moore ym. 2012; Mosenson 2013). Lähestymistavassa SIB avaa yksityisille rahoittajille uusia ansaintamahdollisuuksia (Wilson 2014). Lisäksi SIB-mallin nähdään voivan muuttaa koko sijoitusmarkkinan lähestymistapoja (Nicholls 2013).

Kolmas narratiivi on SIB-mallia kritisoiva varoittava lähestymistapa. Se kyseenalaistaa yksityisen sektorin arvojen tarkoituksenmukaisuuden julkisella sektorilla. Ajattelutavassa SIB edustaa uusliberaalin logiikan laajentumista julkiseen päätöksentekoon, mikä nähdään ongelmallisena kehityksenä. (Warner 2012, 25; Whitfield 2012, 22-23; Warner 2013; McHugh ym. 2013; Malcolmson 2014; Sinclair ym. 2014.) Narratiivin huolena on sosiaalipolitiikan "finansialisoituminen", jonka myötä rahoitussektorin intressit voivat vallata julkista päätöksentekoa (Lake 2015). Narratiivissa yksityisen sektorin arvot sosiaalipolitiikassa ovat kielteinen ilmiö (Fraser ym. 2016, 9). Narratiivi korostaa tulosten mittaamisen ongelmallisuutta ja vaikeutta osoittaa niiden johtuvan SIB-projektista (Fox \& Albertson 2012; Fitzgerald 2013; McHugh ym. 2013; Sinclair ym. 2014).

\section{Aineisto jA Menetelmät}

Artikkeli perustuu laadulliseen tutkimusperinteeseen. Aineistona on 14 helmi-huhtikuussa 2017 suoritettua asiantuntijahaastattelua. Haastattelut olivat yksilöhaastatteluja. Näin ryhmän normatiiviset odotukset eivät vaikuttaneet haastateltujen vastauksiin (Peterson 2005, 265). Haastattelut kestivät puolesta tunnista tuntiin. Litteroitua aineistoa on 88 liuskaa. Haastateltavien 
rekrytointi sähköpostitse onnistui nopeasti.Vain muutama henkilö kieltäytyi haastattelusta vetoamalla joko aikataulusyihin tai vähäiseen tietomääräänsä vaikuttavuusinvestoimisesta. Haastateltavat työskentelivät ministeriöissä, Valtioneuvostossa, rahoitusalalla ja tutkimuslaitoksissa. He ovat vaikuttavuusinvestoimisen asiantuntijoita, ja moni heistä toimi vaikuttavuusinvestoimisen ensimmäisessä kansallisessa ohjausryhmässä. Ryhmä perustettiin joulukuussa 2015 , ja se toimi Sitran alaisuudessa vuoden 2017 loppuun. Sen tavoitteena oli yhdistää vaikuttavuusinvestoimisen sidosryhmiä ja edistää mallin kehittämistä (Pikkarainen 2017). Ryhmän kokoonpano vaihtui vuoden 2018 alussa. Tämän artikkelin aineiston kannalta uudella kokoonpanolla ei ole merkitystä.
Haastattelut toteutettiin puolistrukturoituina teemahaastatteluina, mikä mahdollisti teemasta poikkeamiset ja täsmennykset (Hirsjärvi \& Hurme 2010, 34-36, 47). Haastateltavien valinta perustui heidän institutionaaliseen asemaansa ja kokemukseensa tutkimusaiheesta (ks. Alastalo \& Åkerman 2010, 272). Tällaisessa aineistossa on huomioitava, että haastateltavien tulkinnat vaikuttavuusinvestoimisesta saattoivat heidän työnsä vuoksi heijastaa ainakin osin heidän työnantajiensa näkökulmia. Varauduimme tähän monipuolisella haastattelurungolla ja haastattelemalla erilaisissa tehtävissä toimivia asiantuntijoita.Yksi haastattelu tehtiin puhelimitse ja muut haastateltavien työpaikoilla. Yhtä lukuun ottamatta asiantuntijat antoivat luvan käyttää nimeään, joten

Taulukko 1. Haastateltujen asiantuntijoiden taustatiedot.

\begin{tabular}{|l|l|l|l|l|}
\hline Nimi & Työpaikka & Työtehtävä & Koulutus & Suhde SIBiin \\
\hline Pentti Pikkarainen & Valtiovarainministeriö & Ylijohtaja & FT & Virkamies, ohjausryhmän puheenjohtaja \\
\hline Riikka Sievänen & KPMG & Asiantuntija & FT & $\begin{array}{l}\text { Vastuullisen sijoittamisen asiantuntija, } \\
\text { ohjausryhmän jäsen }\end{array}$ \\
\hline Jari Vaine & Kuntaliitto & Erityisasiantuntija & VTM & $\begin{array}{l}\text { Kuntaliiton edustaja SIB-toiminnassa, } \\
\text { ohjausryhmän jäsen }\end{array}$ \\
\hline Anni Huhtala & VATT & Ylijohtaja & FT & Tutkija, ohjausryhmän jäsen \\
\hline Tom Liljeström & $\begin{array}{l}\text { LähiTapiola } \\
\text { Varainhoito Oy }\end{array}$ & Toimitusjohtaja & DI \& KTM & $\begin{array}{l}\text { Finanssiammattilainen, ohjausryhmän } \\
\text { varapuheenjohtaja }\end{array}$ \\
\hline Jussi Nykänen & Epiqus Oy & Puheenjohtaja & TT & SIB-hankehallinnoijan palveluksessa \\
\hline Jussi Toppila & TEM & Työmarkkinaneuvos & FK & Virkamies, ohjausryhmän varajäsen \\
\hline Kristiina Halonen & Työterveyslaitos & Johtaja & TT & Virkamies SIB-hankkeiden parissa \\
\hline Sonja Hämäläinen & TEM & $\begin{array}{l}\text { Maahanmuutto- } \\
\text { johtaja }\end{array}$ & OTK & Virkamies SIB-hankkeiden parissa \\
\hline Timo Lindholm & Sitra & Johtaja & VTM & Johtaja, ohjausryhmän jäsen \\
\hline Vertti Kiukas & Soste & Päsihteeri & FM & Asiantuntija, ohjausryhmän jäsen \\
\hline Sirpa Kekkonen & VNK & Ohjelmaneuvos & OTK \& & Virkamies, ohjausryhmän jäsen \\
\hline Mika Pyykkö & Sitra & Avainalueen vetäjä & YTM & $\begin{array}{l}\text { Vaikuttavuusinvestoimisen projektijohtaja, } \\
\text { ohjausryhmän jäsen }\end{array}$ \\
\hline Anonyymi & Rahoitusala & Asiantuntija & - & SIB-hankkeiden rahoitustehtävissä \\
\hline
\end{tabular}


anonymisoimme yhden haastatellun tausta- ja tunnistetiedot.

Seuraavissa luvuissa kuvaamme ja jäsennämme SIB-mallin soveltamiseen liittyviä perusteluja ja mallissa nähtyjä ongelmia. Tarkastelemme haastateltavien esiin tuomia perusteluita ja huomioita temaattisesti. Aineiston temaattisen jäsentämisen tukena hyödynnämme Fraserin ym. (2016) esittelemää kolmea narratiivia, ja vertaamme heidän havaintojaan haastatteluissa esiintyviin näkökulmiin. Päädyimme tähän vertailuasetelmaan, koska aiheesta ei ollut saatavilla muita systemaattisia katsauksia, ja koska valittu narratiivinen tulokulma mahdollistaa suomalaisen ja kansainvälisen keskustelun vertailun mallin soveltamisen perusteluiden ja kritiikin osalta. Aineistosta löytyi selviä teemoja ja johtoajatuksia, joilla SIBmallia perustellaan. Näiden teemojen kautta tarkastelemme sitä, missä määrin kansainvälisessä kirjallisuudessa esiintyvät narratiivit ilmenevät suomalaisessa SIB-keskustelussa.

\section{UUSIA RATKAISUJA JULKISEN SEKTORIN TOIMINTAAN}

Kansainvälisessä kirjallisuudessa esiintyvä julkisen sektorin uudistamisnarratiivi SIB-järjestelyjen perusteluna korostaa julkisten toimijoiden ongelmia palvelutuotannon järjestämisessä ja toteutuksessa. Tulosperusteisten rahoitussopimusten myötä julkiselle sektorille tuodaan yksityisen sektorin johtamisjärjestelmiä ja kannustemalleja. Nämä toimintatavat nähdään keskeisenä ratkaisukeinona esitettyihin ongelmiin. (Mulgan ym. 2011; HM Government 2011 \& 2013; Liebman
2011.) Tämä puhetapa tulee esiin myös haastatteluissa. Osa haastatelluista näkee, että julkisen sektorin olisi ostettava nimenomaan tuloksia ja maksettava tehokkuudesta. Tästä näkökulmasta SIB voi toimia välivaiheena kohti yhä vahvemmin tulosten ostamiseen tähtäävää toimintaa (ks. Lagarde ym. 2013). Näkökulmaa korostavat etenkin Sitran asiantuntijat.

"...SIB työkaluna on vähän niin kun siirtymävaiheen työkalu sillä polulla, jossa sitten perimmäisenä tavoitteena on se, että julkisen sektorin toimijat pystyisivät hankkimaan tuloksia...”(Lindholm, Sitra)

"...suurin mahdollisuus liittyy siihen, että tässähän on kyse kuitenkin hyvin isoista ajattelutavan muutoksista julkisen sektorin toiminnassa. Sekä siinä, että tilataan tuloksia, että myös siinä, että suhtaudutaan joustavasti siihen, että missä on sitä hyödyllistä osaamista niiden tulosten aikaan saamiseksi...” (Pikkarainen,VM)

Kansainvälisen kirjallisuuden uudistamisnarratiivissa SIB-mallin tarjoamat mahdollisuudet julkisen ja yksityisen toiminnan arvojen yhdistämiselle näyttävät hyödyllisiltä (Fraser ym. 2016, 6). Tältä osin suomalainen keskustelu mukailee kansainvälisiä näkemyksiä. Haastateltujen mukaan tulosten ostaminen voi johtaa tuottavampiin ja laadukkaampiin palveluihin. Paremmat palvelut nousevat haastateltujen näkemyksistä esiin asiana, jonka SIB voi mahdollistaa. Tämä on eräs SIBin soveltamisen peruste.

”...Perusteena on varmasti just se, että näin voidaan tehdä julkisen sektorin tekemisestä tuottavampaa, ja sitten parantaa ihmisten palveluita...” (Hämäläinen, TEM) 
Osa asiantuntijoista korostaa, että SIB voi viedä julkista sektoria kohti ennakoivampaa toimintaa. He näkevät julkisen sektorin nykyisen panoksen ennaltaehkäiseviin hyvinvointipalveluihin riittämättömänä. Tältä osin suomalainen keskustelu yhdistyy kansainväliseen keskusteluun, jossa korostuvat julkisen sektorin ongelmat palveluiden järjestämisessä (Mulgan ym. 2011; HM Government 2011 \& 2013; Liebman 2011).

"...mahdollisuutena on tietenkin se, että ennaltaehkäiseviin palveluihin tulee suurempi painotus, kun tällä hetkellä. Tällä hetkellä meillä käytetään huomattavasti enemmän rahaa korjaaviin palveluihin, kun ennaltaehkäiseviin palveluihin. SIB voi onnistuessaan kääntää tätä asetelmaa päinvastoin..." (Anonyymi, rahoitusala)

Kaiken kaikkiaan kiinnostavaa on se, että osa haastatelluista ei näe SIB-mallia ainoastaan rahoituksen täydentäjänä, vaan uudenlaisena keinona tehdä sosiaalipolitiikkaa ja kehittää palveluita. Myös tältä osin suomalaisessa ja kansainvälisessä keskustelussa voidaan nähdä yhtäläisyyksiä.

"...SIB:it ei oo rahotusinstrumentti, vaan ne on väline tehdä yhteiskuntapolitiikkaa. Ne on semmonen lisä sille. Ei ne voi korvata valtion tehtävii. Ne ei voi korjata budjettirahotusta. Mut ne voi olla semmonen..ehkä pari piirua joustavampi lisä, jolla tätä voidaan tehä. Niin mä nään sen filosofian, mut en mä lähtis kaventamaan sitä filosofiaa rahotusinstrumentiks, et nyt yksityinen on mukana rahottamas julkista hallintoo. Kyl mä nään sen myös palveluiden kehittämisen instrumenttina...” (Hämäläinen, TEM)
Suomalaisessa keskustelussa ilmenee huoli työttömyydestä ja julkisesta taloudesta keskeisenä perusteluna SIBmallia hyödyntäville uudistuksille. Valtaosa haastatelluista korostaa, ettei hyvinvointijärjestelmä ole taloudellisesti kestävä. Haastateltujen mukaan SIB voi pienentää julkisen sektorin budjettipaineita. Keskeinen peruste SIBin soveltamiselle Suomessa on rahoitusriskin siirtyminen yksityiselle sektorille. Sekä suomalaisessa että kansainvälisessä keskustelussa korostuu, että SIBin soveltaminen voi houkutella hallituksia juuri rahoitusriskin siirtymisen vuoksi. Tämä vähentää projektin aikana vaadittavia julkisia panostuksia (Mulgan ym. 2011; Social Finance 2011; Callanan \& Law 2012; Rotheroe ym. 2013).

"...tarvitaan näitten palvelujen tuottamiseen sitten muitakin rahoitusmahdollisuuksia, kun tää julkinen hyvin tiukalla oleva rahoitus..." (Toppila, TEM)

"...me on ajauduttu tämmöseen tilanteeseen, niin meidän julkinen talous on kestämättömällä uralla...” (Pikkarainen,VM)

Budjettipaineiden pienentymiseen liittyvien näkökulmien ohella haastatteluissa on yksittäisiä havaintoja siitä, että SIB voi murtaa julkisen sektorin monopolia palvelutuotannossa. Palvelutuotantoon ja julkisen sektorin rooliin liittyvät huomiot ovat mielenkiintoisia juuri sosiaali- ja terveyssektoriin kohdistuvien uudistuspaineiden näkökulmasta.

"...tässä hyvinvointirakenteessa on sitten yksityinen pääoma rahottamassa ja kehittämässä näitä hyvinvointirakenteita, eli tää yhteiskunnan monopolistinen rooli niin tältä osin muuttuu, niin se on varmaan se 
nimenomaan SIBiin liittyvä kysymys..." (Toppila,VM)

Osa haastatelluista näkee SIBin väylänä julkisen, yksityisen ja järjestösektorin yhteistyön lisäämiseen ja kehittämiseen. Tältä osin suomalaisten asiantuntijoiden näkemyksissä on samankaltaisia painotuksia kuin julkisen sektorin uudistamisnarratiivissa (ks. Fraser ym. 2016, 6). Yhteistyöllä tavoitellaan eri sektoreiden käyttämättömiä resursseja. Haastateltujen mukaan tästä voi syntyä uusia toimintamalleja. Resurssien aktivointi näyttäytyy haastatteluissa SIBmallin soveltamisen perusteluna. Aktivointi liittyy ajatukseen, jonka mukaan jokainen sektori voi tarjota yhteiseen käyttöön hyviä käytäntöjä.

”...tää on yks tapa kehittää kuitenkin julkisen, yksityisen ja järjestösektorin yhteistyötä. Siitä on paljon Suomessa puhuttu, mutta siinä on paljon varmasti vielä käyttämätöntä potentiaalia...” (Pyykkö, Sitra)

Lisäksi osa haastatelluista toteaa, että SIB haastaa yksityisen sektorin tehokkuuspuheen. Haastatellut korostavat, että SIBin avulla julkinen sektori pääsee testaamaan yksityisen sektorin tehokkuusväitteet.

”...meil on jo tullut tää fraseologia et "no joo et se on niitä valtion touhuja" ja näin ja sitten mielikuva, että se yksityinen on jotenkin ketterämpi ja toimivampi niin, niin tässä vähän haetaan sitä sanasta miestä, että onks se näin, mikä se on se yksityisen puolen osaaminen, mikä nyt sielt valtiolta puuttuu...” (Huhtala,VATT)
YKSITYISEN RAHOITUSSEKTORIN MUUTOS?

Yksityisen rahoitussektorin uudistamisnarratiivi korostaa, että yksityisen ja julkisen sektorin arvoja yhdistämällä yksityisen sektorin toimijoille, etenkin rahoitussektorille, tarjoutuu mahdollisuuksia liiketoimintaan yhteiskunnallisesti kestäviä muutoksia tavoittelevan yhteiskunnallisen yrittäjyyden avulla (Social Investment Task Force 2010; Cohen 2011; Liebman 2011; Nicholls \& Murdock 2012; Moore ym. 2012; Mosenson 2013). Suomalaisessa keskustelussa yksityisen rahoitussektorin uudistuminen SIBin myötä yhteiskuntavastuullisempaan suuntaan ei kuitenkaan juuri näy kuin yksittäisinä kommentteina.

"...Sijottajalle se on tietenkin kohtuullisen ison riskin sisältävä sijotusinstrumentti, joka kuitenkin hyvin konkreettisesti antaa mahdollisuuden sen mitattavan yhteiskunnallisen hyvän aikaansaamiseen...” (Pyykkö, Sitra)

Rahoitussektorin uudistumisen sijaan haastatteluissa viitataan lähinnä yksityisten sijoittajien merkityksen lisääntymiseen sosiaalipoliittisissa ratkaisuissa.

”...tämmönen instrumentti, jossa voidaan tuoda yksityinen raha ratkasemaan yhteiskunnallisia ongelmia, niin sille on ehdoton tilaus tällä hetkellä yhteiskunnassa...” (Nykänen, Epiqus)

Kansainvälisessä keskustelussa korostuu toive vaikuttavuussijoitusmarkkinan kasvusta (Liebman 2011, 28; Cohen 2011; HM Government 2011, 2013; Clark ym. 2014). Samankaltaista ajatusta sijoitusmarkkinan kasvusta ei Suomessa ole, vaan SIB-sijoittamisen ole- 
tetaan pysyvän pienimuotoisena. Tältä osin suomalainen ja kansainvälinen keskustelu selvästi eroavat.

"...nää saavuttaa semmosen tietyn roolin sijottajissa niin, että niistä ei koskaan tuu hirveen suuri juttu, se on vähän tämmönen erilainen, erikoinen homma. Mut että niihin tulee joku semmonen luonteva, pieni allokaatio et, jos nyt esimerkkinä ottaa sen, että vaikka joku säätiö tai vastaava hoitaa varojaan niin ehkä totee, että $0-2 \%$ varoista voi olla sijotettuna vaikuttavuuskohteeseen..." (Liljeström, LähiTapiola)

Valtaosa rahoitussektorin uudistamisnarratiiviin linkittyvästä kansainvälisestä kirjallisuudesta käsittelee SIB-sijoittamisen tekemistä houkuttelevammaksi riskejä pienentämällä (Cox 2011; Bafford 2012; Burand 2012; Leventhal 2012; Dagher 2013; Shiller 2013). Suomalaisessa keskustelussa tämä ei korostu muuten kuin vähäisinä mainintoina pääomaturvasta, joka tekisi sijoittamisesta houkuttelevampaa takaamalla osan sijoitetusta summasta.

”...jos saadaan jostain pääomaturva tai osittain pääomaturva, niin sitten taas se tuotto voi olla siellä lähempänä kahta prosenttia..." (Nykänen, Epiqus)

\section{SIB-MALLIN RISKIT}

Sekä kansainvälisessä että suomalaisessa keskustelussa SIB-malliin liitetään riskejä. Yksi keskeinen riski on tulosmittareiden kehittämisen vaikeus. Jos mittarit laaditaan väärin tai huonosti, on mahdollista, että ne eivät kohdistu SIB-projektin vaikutuksiin. Näiltä osin huoli on yhtenäinen kansainvälisen tutkimuskirjallisuuden kanssa (ks. Fox
\& Albertson 2012; Fitzgerald 2013; McHugh ym. 2013; Sinclair ym. 2014). Haastatteluissa korostuu SIBin monimutkaisuus olennaisena riskitekijänä. SIBin haasteena ovat sen edellyttämät selkeät sopimukset vastuista, tavoitteista ja mahdollisista riitatilanteista. Suomessa hankkeiden sopimusmuodot eivät ole vakiintuneet, joten ne vaativat paljon valmistelua. (Hilli ym. 2015, 14.)

”...Riskinä voi olla se, että ne mittarit, jos niitä ei loppuun asti mietitä, niin ne ohjaa väärään suuntaan..." (Anonyymi, rahoitusala)

Haastattelujen perusteella myös polarisaatio on yksi SIB-mallin riski. Voi syntyä houkutus olla kohdistamatta SIB-hanketta alueille, joissa on enemmän sosiaalisia ongelmia. Huoli yhdistyy joidenkin asiantuntijoiden näkökulmissa SIB-projektin kohderyhmän pienuuteen.

"...liittyy jonkinlainen polarisointiriski, että ne alueet, missä asiat vois olla paremmin niin niihin ei kannata panostaa, koska se näkymä tai aikaikkuna parantumiselle on sen verran haasteellisempi, kun joku toinen paikkakunta, missä vaikuttavuutta saa ehkä todennäkösemmin ja nopeemmin..." (Liljeström, LähiTapiola)

Lisäksi haastatteluaineistossa toistuu riski projektien epäonnistumisesta. Huoli kohdistuu etenkin yksityisen sijoittajan kantaman taloudellisen riskin realisoitumiseen ja siihen, että tämän jälkeen uusien SIB-sijoittajien löytäminen voi olla hankalaa.

”...riski tietysti on se, että jos käy sillä tavalla, että sijottajat menettää koko pääoman ja ei nää enää koskaan rahoistaan, niin se- 
kin olis negatiivista, et sitä on aika paljon vaikeempi selittää seuraaville sijottajille..." (Nykänen, Epiqus)

Kansainvälisessä kirjallisuudessa SIBin oleellisena riskinä pidetään, että se voi johtaa julkisten toimintojen yksityistämiseen (Whitfield 2012; McHugh ym. 2013; Joy \& Shields 2013). Haastatelluissa tämä ei korostu, vaan SIB-mallin pelätään ainoastaan herättävän kielteisiä mielikuvia julkisen sektorin yksityistämisprojektista.

”...en haluais sitä mielikuvaa ja tulkintaa liikaa korostaa, että tämä on jonkunlainen sosiaalipuolen yksityistämisprosessi..." (Lindholm, Sitra)

Osa haastatelluista korostaa SIBin riskinä sitä, että hankehallinnoija voi laiminlyödä joidenkin toimijoiden odotuksia ja päämääriä. Kansainvälisessä kirjallisuudessa korostuu, että SIB vaatii paljon ulkopuolista osaamista onnistuakseen. Tältä osin suomalainen keskustelu menee osittain yhteen kansainvälisen kirjallisuuden kanssa, jossa korostuvat toimijoiden tarpeet ja valvonta (Warner 2012, 2013).

”...täshän on monta intressiä tähän näin, niin miten me varmistutaan siitä, että hankehallinnoija ottaa nää kaikki intressit huomioon..." (Hämäläinen, TEM)

Osa haastatelluista toteaa sijoittajien ylituottojen olevan SIBin riski. Jos sijoittaja saa suuren voiton, voi syntyä epäilys, että sijoittaja hyötyy sosiaalisesta ongelmasta. Huoli ei ole aineistossa yleinen, mutta se on kiinnostava, koska siihen liittyy ajatus kohtuullisista voitoista. ”...jos mennään sinne, että tästä yhtäkkiä tulee hirvee rahasampo, niin se kääntyy sijottajia vastaan, että sillon siitä tulee se backlash, että te tienaatte yhteiskunnallisilla ongelmilla...” (Nykänen, Epiqus)

Osa asiantuntijoista näkee riskinä SIBhankkeiden onnistumiselle rahastonrakentajan eli hankehallinnoijan liiketaloutta korostavat intressit. Tällöin SIB-mallista tulee rahastonrakentajan edun mukainen, ja sosiaalisten ja liiketaloudellisten intressien välille syntyy ristiriita. Näkökulmassa on viitteitä kansainvälisessä kirjallisuudessa esiintyvästä varoittavasta narratiivista, jossa yksityisen sektorin arvot ja toimintalogiikka eivät sovellu ongelmitta sosiaalipolitiikkaan (Warner 2012, 25; Warner 2013; Whitfield 2012, 22-23; McHugh ym. 2013; Malcolmson 2014; Sinclair ym. 2014). Suomalaisesta aineistosta välittyvä huoli ei näiltä osin ole yhtä vahva ja selkeä.

"...siinä on tahoja mukana rakentamassa itse näitä bondeja, joiden intressit ei välttämättä oo tän asiakastahon eikä välttämättä sijottajankaan tai toimijan intressin mukasia, vaan yleensähän rahastorakenteen tekijän intressihän on se, että rahastonhoitaja menestyy...” (Liljeström, LähiTapiola)

\section{YHTEENVETO}

Valittu narratiiviperusteinen analyysitapa osoittautui tutkimuksessamme toimivaksi. Sen avulla tavoitimme oleellisia teemoja, joilla SIBin soveltamista perustellaan Suomessa. Kansainvälisten narratiivien ja suomalaisen keskustelun vertailu osoittaa keskustelutapojen erot ja samankaltaisuudet. Narratiivilla tarkoitamme tässä yhteydessä tutkimus- 
aiheesta vallitsevaa keskustelutapaa.Vaikuttavuusinvestoimisen erottaa perinteisestä julkisen sektorin toteuttamasta sosiaalipolitiikasta se, että hankkeet toimivat yksityisellä rahoitusriskillä. Keskeinen ero vakiintuneisiin yksityistä ja julkista sektoria yhdistäviin toimintamalleihin (esim. ostopalvelut) on siinä, että SIB-mallissa julkinen toimija ostaa palveluiden sijaan tuloksia. Mallin suurimpia haasteita on toiminnan tuloksellisuutta kuvaavien mittareiden laadinta. Mittareiden laatimisessa on ymmärrettävä tarkasti, mitä mitataan, kuinka mitataan ja millainen on vertailuryhmä. Mittareiden luotettavuuteen liittyvät riskit korostuvat sekä kansainvälisessä että suomalaisessa keskustelussa.Voi olla vaikeaa osoittaa, että tietyt tulokset ovat juuri SIBin seurausta (ks. Fox \& Albertson 2011; Fitzgerald 2013; McHugh ym. 2013; Sinclair ym. 2014). Lisäksi SIBin heikkoutena on sen työläys. SIB-mallia on sovellettu vuosia etenkin Yhdysvalloissa ja Isossa-Britanniassa. Uutta on mallin saapuminen suomalaiseen hyvinvointivaltioon, jossa sosiaalipoliittiset toimet ovat olleet etäämmällä yksityisen sektorin toiminnasta kuin angloamerikkalaisessa perinteessä. Suomessa SIB tunnetaan vielä heikosti. Mallin merkittävin puolestapuhuja on Suomessa ollut Sitra.

SIB-mallia perustellaan Suomessa kolmesta lähtökohdasta käsin. Ensimmäinen on heikko julkinen talous ja mahdollisuus siirtää mallin avulla rahoitusriskiä julkisilta toimijoilta yksityisille sijoittajille. Kansainvälisessä keskustelussa korostuu rahoitusriskin siirtäminen yksityiselle sektorille, mutta siinä julkisen talouden heikko tila ei painotu yhtä vahvasti kuin suomalaisessa asiantuntijakeskustelussa (ks. Mulgan ym. 2011; Social Finance 2011; Callanan \& Law 2012; Rotheroe ym. 2013). Suomalaisessa keskustelussa SIB-mallin ajatellaan helpottavan budjettipaineita. Toisena perusteluna SIBin soveltamiselle ovat sen mahdollistamat laadukkaammat ja räätälöidymmät sosiaali- ja terveyssektorin palvelut. Perustelu nojaa oletukseen siitä, että palveluntuottajat pyrkivät SIB-mallissa kohdentamaan palvelut paremmin kohderyhmälle. Kansainvälinen keskustelu korostaa myös räätälöityjen palveluiden merkitystä, joten siltä osin kansainvälinen ja suomalainen keskustelu kohtaavat (ks. Leventhal 2012; Jackson 2013, 608613; Clark ym. 2014). Kolmas soveltamisperuste on SIB-mallin mahdollistama yhteistyö eri sektoreiden välillä. Yhteistyö voi aktivoida käyttämättömiä resursseja ja johtaa uusiin toimintamalleihin. Tämän ajatellaan tukevan parempien ja tehokkaampien palveluiden kehittämistä. SIBin yhteiskuntapoliittisesti merkittävä osa on kohderyhmän aktivointi tavoitteiden saavuttamiseksi. Kansainvälisessäkin keskustelussa painottuu sektorien välisen yhteistyön merkitys (Fraser ym. 2016, 6). Tältä osin suomalainen ja kansainvälinen keskustelu painottavat samoja teemoja. SIBin toimintalogiikassa voi nähdä yhteyksiä sellaiseen hyvinvointivaltion kritiikkiin, jonka mukaan sosiaalietuudet passivoivat ihmisiä (ks. Kotkas 2012, 1193). SIB-projekteihin valitut ovat vapaaehtoisia, joten näiltä osin SIBin toimintatapa eroaa perinteisestä sosiaaliturvasta.

1980-luvulta alkaen julkista sektoria on muokattu ja virtaviivaistettu kohti yksityisen sektorin johtamis- ja toimintatapoja. Sosiaalisiin ongelmiin ja sosiaaliturvaan on sovellettu perinteisesti julkisen palvelutuotannon ja jul- 
kisen sektorin luomia ratkaisumalleja. SIB muuttaa tätä toimintalogiikkaa, koska siinä sosiaalinen ongelma tai palvelutarve rakennetaan yksityisen sektorin rahoitusinstrumentiksi, jonka avulla ongelma pyritään ratkaisemaan. Kehitys on osa jatkumoa, jossa hyvinvointivaltiolliset prosessit soveltavat yhä enemmän markkinamekanismeja (ks. Mänttäri-van der Kuip 2013, 5). Samalla SIB on yksi lisä kasvavien rahoitusmarkkinoiden sijoitusinstrumenttivalikoimassa.

Vaikuttavuusinvestoimisen ja tulosperusteisen rahoitussopimuksen suomenkieliset termit eivät ole vielä vakiintuneet. Käytössä oleva Sitran käännös kuvaa vaikuttavuusinvestoimisen osalta (Impact Investing) jossain määrin termin englanninkielistä vastinetta. Käännös ei kuitenkaan huomioi, että vaikuttavuuskeskustelussa termeillä "impact" ja "effect" tarkoitetaan jonkin toimintamallin tai prosessin tuottamaa muutosta, joka voi tapahtua tai olla tapahtumatta. Sen sijaan vaikuttavuutta kuvaava termi "effectiveness" kertoo, kuinka valittu prosessi tai toimintamalli tuottaa muutoksen. Tulosperusteisen rahoitussopimuksen (Social Impact Bond) osalta Sitran käännös ei sen sijaan huomioi lainkaan social-sanaa. Tämä on ongelmallista, koska SIB-projekteihin liittyy sosiaalinen ulottuvuus, ja niiden tarkoituksena on aikaansaada sosiaalista hyötyä. Tämä ulottuvuus tulee esiin termissä sosiaalinen tulosrahoitus, jota ehdotamme vaihtoehtoiseksi käännökseksi Social Impact Bond -termille. Sosiaalinen tulosrahoitus kuvaa sekä mallin sosiaalista luonnetta että sen tulostavoitteita.

\section{ЈOHTOPÄÄTÖKSET}

Hyvinvointimallien uudistamisessa ja liberalisoinnissa tehdään jatkuvasti yksittäisiä niukkoja toimenpiteitä, jotka voivat yhdessä vaikuttaa koko hyvinvointimallin suuntaan (Kantola 2002, 193; Julkunen 2017,13). On vielä aikaista arvioida, kuinka suuresta muutoksesta SIB-mallin käyttöönottamisessa lopulta on kyse. Sen yhteydessä voidaan kuitenkin puhua hyvinvointimallin rajatusta uudistamisesta, koska SIB ottaa mukaan sosiaalipolitiikan toteutukseen puhtaita markkinaelementtejä vielä vahvemmin kuin aiemmat yksityisen ja julkisen sektorin kumppanuudet. SIBmallissa markkinamekanismin avulla koetetaan ratkaista ongelmia, jotka ovat syntyneet osittain julkisten interventioiden heikon vaikuttavuuden tuloksena.

Koskiaho $(2008,10)$ esitti kymmenen vuotta sitten arvion brittiläisten hyvinvointimallien saapumisesta Suomeen. SIB-mallin soveltaminen on yksittäinen mutta selkeä askel tähän suuntaan. Suomessa SIB-mallia on sovellettu muutaman vuoden ajan, ja projektit ovat kesken, joten lopullisia tuloksia mallin toimivuudesta ei ole vielä saatavilla. Koskiaho (mt.) huomautti myös uusien hyvinvointimallien riskeistä: voiko käydä niin, ettei näitä malleja soveltaneiden maiden virheistä opita ja malleja analysoida kriittisesti? Tähän on vielä aikaista ottaa kantaa, mutta näyttää siltä, että Suomessa SIB nähdään melko positiivisesti uutena sosiaalipoliittisena mahdollisuutena. SIB siirtää valtaa toteutettavien projektien osalta yksityisille toimijoille, mutta tämän valtasiirtymän vaikutuksia on vielä vaikea arvioida. Projekteissa on mukana monia 
yksityisiä tahoja, mutta julkinen sektori on toiminnan tilaaja. Tältä osin SIB ei siis muuta toimintalogiikkaa verrattuna perinteisiin ostopalveluihin.

Suomalaisessa keskustelussa tunnistetaan malliin kuuluvat mitattavuuteen ja polarisaatioon liittyvät riskit. Kansainvälisessä kontekstissa on esitetty huolia myös markkinariskeistä, jotka liittyvät vaikuttavuusinvestoimisen lupausten ja todellisuuden välisen eron kasvamiseen (ks. Wilson 2014, 29). Kansainvälinen sosiaalinen rahoitusmarkkina on Suomen vastaavaa markkinaa suurempi, ja Suomen mittakaavassa markkinariskit ovat vähäisempiä. Suomessa riskit kohdistuvat ennemmin mallin mittareiden laatimiseen, palveluntarjonnan tasapuoliseen saavutettavuuteen ja siihen, kuinka yksityisen sektorin arvot soveltuvat sosiaalipolitiikan toteutukseen. Näiden riskien toteutumisesta ei ole vielä kokemuksia.

\section{KirJallisuUs}

Alasuutari, Pertti (2004) Suunnittelutaloudesta kilpailutalouteen. Miten muutos oli ideologisesti mahdollinen? Yhteiskuntapolitiikka 69 (1), 3-16.

Alastalo, Marja \& Àkerman, Maria (2010) Asiantuntijahaastattelun analyysi: faktojen jäljillä. Teoksessa Johanna Ruusuvuori, Pirjo Nikander \& Matti Hyvärinen (toim.) Haastattelun analyysi. Tampere: Vastapaino, 372-392.

Alavaikko, Mika (2007) Valtakunnallisen sosiaalipolitiikan loppu - keskitetystä ohjauksesta alueellisiin kehittämishankkeisiin. Teoksessa Kati Rantala \& Pekka Sulkunen (toim.) Projektiyhteiskunnan kääntöpuolia. Helsinki: Gaudeamus, 39-55.

Bafford, Beth (2012) The feasibility and future of social impact bonds in the United States, Sanford. Journal of Public Policy
3 (1), 3-19.

Bugg-Levine, Antony \& Emerson, Jed (2011) Impact Investing. Transforming How We Make Money while Making a Diffirence. Innovations 6 (3) 9-18. https://doi.org/10.1162/inov_a_00077

Burand, Deborah (2012) Globalizing social finance: How social impact bonds and social impact performance guarantees can scale development. N.Y.U. Journal of Law and Business 9 (2), 447-502.

Callanan, Laura \& Law, Jonathan (2012) Will Social Impact Bonds Work in the United States? Washington, DC: McKinsey on Society. http://www.mspartners. org/images/papers/8-McKinsey\%20 on $\% 20$ Social-impact-bonds.pdf luettu 27.2.2018.

Cohen, Ronald (2011) Harnessing social entrepreneurship and investment to bridge the social divide. EU conference on the social economy/November 18th 2011. http://ec.europa.eu/internal_market/social_business/docs/conference/cohen_en.pdf luettu 13.1.2018.

Cox, Benjamin R. (2011) Financing homelessness prevention programs with social impact bonds. Review of Banking \& Financial Law 31 (2), 959-985.

Clark, Michael \& David, Clifford C. Jr \& Hwang, Jason \& Moses, Nancy \& Nelson, Suzy \& Torres, Nicholas D. (2014) Next-generation nonprofits. Teoksessa Tine Hansen-Turton \& Nicholas D. Torres (toim.) Social Innovation and Impact in Nonprofit Leadership. New York, New York: Springer, 63-81. https://doi. org/10.1080/08841233.2015.1026790

Dagher, Peter G. Jr. (2013) Social impact bonds and the private benefit doctrine: Will participation jeopardize a nonprofit's tax-exempt status, Fordham Law Review 81 (6), 3479-3519.

de la Peña, Inés (2015) A primer on a social impact bonds. Eclac: United Nations. http://www.cepal.org/sites/default/ files/news/files/wp_pena_2.pdf luettu 24.11.2017.

Den Heyer, Garth (2011) New public management. Policing: An International Journal of Police Strategies \& $\mathrm{Ma}-$ nagement 34 (3), 419-433. https://doi. org/10.1108/13639511111157492

Ferlie, Ewan \& Ashburner, Lynn \& Fitzger- 
ald, Louise \& Pettigrew, Andrew (1996) The New Public Management in Action. Oxford: Oxford University Press. https://doi.org/10.1093/acprof:o so/9780198289029.001.0001

Fitzgerald, John L. (2013) Social impact bonds and their application to preventive health. Australian Health Review 37 (2), 199-204. https://doi.org/10.1071/ ah12238

Forma, Pauli \& Kuivalainen, Susan \& Niemelä, Mikko \& Saarinen, Arttu (2007) Kuinka hyvinvointivaltion kesytetään? Julkisen sektorin uudistaminen ja hyvinvointipalvelujen muutos Pohjoismaissa. Turku: Turun yliopiston Sosiaalipolitiikan laitoksen julkaisuja B:32.

Fox, Chris \& Albertson, Kevin (2012) Is payment by results the most efficient way to address the challenges faced by the criminal justice sector? Probation Journal 59 (4), 355-373. https://doi. org $/ 10.1177 / 0264550512458473$

Fraser, Alec \& Tan, Stefanie \& Lagarde, Mylene \& Mays, Nicholas (2016) Narratives of promise, narratives of caution: A review of the literature on Social Impact Bonds. Social Policy \& Administration 52 (1), 1-25. https://doi.org/10.1111/ spol.12260

Hallituksen puoliväliriihi (2017) Nuorten syrjäytymisen vähentäminen. NEET-toimenpiteen ministereille 25.4.2017. Hallituksen muistio.

Harji, Karim \& Jackson, Edwart T. (2012) Accelerating Impact. Achievements, Challenges and What's Next in Building the Impact Investment Industry. New York: The Rockefeller Foundation.

Heikkilä, Matti (1997) Leikkausten hinta: Tutkimuksia sosiaaliturvan leikkauksista ja niiden vaikutuksista 1990-luvun Suomessa. Helsinki: Stakes.

Heiskala, Risto \& Luhtakallio, Eeva (2006) Johdanto: Suunnittelutaloudesta kilpailukyky-yhteiskuntaan? Teoksessa Risto Heiskala \& Eeva Luhtakallio (toim.) Uusi jako. Miten Suomesta tuli kilpailukykyyhteiskunta. Helsinki: Gaudeamus, 7-13.

Hiilamo, Heikki \& Niemelä, Heikki \& Pykälä, Pertti \& Riihelä, Marja \& Vanne, Reijo (2012) Sosiaaliturva ja elämänvaiheet. Suomen sosiaaliturvan kehitys esimerkkien ja tilastojen valossa. Helsinki:
Kelan tutkimusosasto.

Hilli, Petri \& Karttunen, Marja \& Keltanen, Taru \& Pyykkö, Mika \& Rautio, Sari (2015) SIB-opas julkiselle sektorille. Tulosperusteinen rahoitussopimus käytännössä. Sitran selvityksiä. Helsinki: Sitra.

Hirsjärvi, Sirkka \& Hurme, Helena (2010) Tutkimushaastattelu. Teemahaastattelun teoria ja käytäntö. Helsinki: Gaudeamus.

HM Government (2011) Growing the Social Investment Market: A vision and a strategy. https://www.gov.uk/government/uploads/system/uploads/attachment_data/file/61185/404970_SocialInvestmentMarket_acc.pdf luettu 13.1.2018.

HM Government (2013) Open Public Services. https://www.gov.uk/government/uploads/system/uploads/ attachment_data/file/200077/Open_ Public_Services_2013_full_report.pdf luettu 13.1.2018.

Horesh, Ronnie (1988) Social Policy Bonds. Discussion Paper No. 121. Agribusiness and Economics Research Unit. Canterbury: Lincoln College, 266-280. https:// researcharchive.lincoln.ac.nz/bitstream/ handle/10182/848/aeru_dp_121_vol2. pdf? sequence $=2 \&$ is Allowed $=y$ luettu 9.1.2018.

Horesh, Ronnie (2000) Injecting incentives into the solution of social problems: Social policy bonds. Economic Affairs 20 (3), 39-42. https://doi. org/10.1111/1468-0270.00237

Jolliffe, Darrick \& Hedderman, Carol (2014) Peterborough Social impact bond: final report on cohort 1 analysis. QinetiQ. Leicester: University of Leicester.

Joy, Meghan \& Shields, John (2013) Social impact bonds: The next phase of third sector marketization? Canadian Journal of Nonprofit and Social Economy Research 4 (2), 39-55. https://doi. org/10.22230/cjnser.2013v4n2a148

Julkunen, Raija (2001) Suunnanmuutos: 1990-luvun sosiaalipoliittinen reformi Suomessa. Tampere:Vastapaino.

Julkunen, Raija (2006) Kuka vastaa? Hyvinvointivaltion rajat ja julkinen vastuu. Helsinki: Stakes.

Julkunen, Raija (2017) Muuttuvan hyvinvointivaltiot. Eurooppalaiset hyvinvointivaltiot reformoitavana. Jyväskylä: SoPhi. 
Junnila, Maijaliisa \& Fredriksson, Sami (2012) Tilaaminen ja tuottaminen sosiaali- ja terveyspalveluissa. Palvelujen ulkoistus. Kide 19. Helsinki: Terveyden ja hyvinvoinnin laitos.

Kananen, Johannes (2008) Kilpailukyky ja tuottavuus 2000-luvun sosiaalipolitiikassa.Yhteiskuntapolitiikka 73 (3), 239-249.

Kantola, Anu (2002) Markkinakuri ja managerivalta. Helsinki: Lokikirjat.

Kiander, Jaakko (2001) Laman opetukset: Suomen 1990-luvun kriisin syyt ja seuraukset. Helsinki: Valtion taloudellinen tutkimuskeskus.

Kiander, Jaakko \& Lönnqvist, Henrik (2002) Hyvinvointivaltio, sosiaalipolitiikka ja taloudellinen kasvu. Helsinki: Sosiaali- ja terveysministeriö.

Koskiaho, Briitta (2008) Hyvinvointipalvelujen tavaratalossa: Palvelutalous ja sosiaalipolitiikka Englannissa, Ruotsissa ja Suomessa. Tampere:Vastapaino.

Koskiaho, Briitta (2014) Kumppanuuden sosiaalipolitiikkaa etsimässä. Tallinna: United Press.

Kosonen, Pekka (1998) Pohjoismaiset mallit murroksessa. Tampere:Vastapaino.

Kotkas, Toomas (2012) Sopimuksellisuus sosiaalioikeudessa - esimerkkinä julkisen työvoimapalvelun ja työttömyysturvan asiakassuunnitelmat. Lakimies 110 (7-8), 1187-1204.

Kovalainen, Anne (2004) Hyvinvointipalvelujen markkinoituminen ja sukupuolisopimuksen muutos. Teoksessa Lea Henriksson \& Sirpa Wrede (toim.) Hyvinvointityön ammatit. Helsinki: Gaudeamus, 187-209.

Laatu, Markku (2009) Missä kulkevat sosiaalipalvelujen kaupallistamisen riskirajat? Yhteiskuntapolitiikka 74 (1), 80-83.

Lagarde, Mylene \& Wright, Michael \& Nossiter, Julie \& Mays, Nicholas (2013) Challenges of Payment-for-Performance in Health Care and Other Public Services - Design, Implementation and Evaluation. London: PIRU Publications.

Laine, Juha \& Valtonen, Hannu (2004) Hoivapalvelujen tuottavuudesta ja laadusta. Yhteiskuntapolitiikka 69 (4), 407-411.

Lake, Robert W. (2015) The financialization of urban policy in the age of Obama. Journal of Urban Affairs 37 (1), 75-78. https://doi.org/10.1111/juaf.12167
Leventhal, Rebecca (2012) Effecting progress: Using social impact bonds to finance social services. N.Y.U. Journal Of Law and Business 9, 511-534.

Liebman, Jeffrey B. (2011) Social Impact Bonds: A promising new financing model to accelerate social innovation and improve government performance. Center for American Progress 9. Washington DC: Center for American Progress

Liebman, Jeffrey \& Sellman, Alina (2013) Social Impact Bonds: A Guide for States and Local Governments. Cambridge, MA: Harvard Kennedy School Government Performance Lab.

Malcolmson, John D. (2014) Social impact bonds: cleared for landing in British Columbia. BC Region: CUPE Research. https://cupe.ca/sites/cupe/files/Research_note-_SIBs_come_to_BC.pdf luettu 15.1.2018.

McHugh, Neil \& Sinclair, Stephen \& Roy, Michael \& Huckfield, Leslie \& Donaldson, Cam (2013) Social impact bonds: A wolf in sheep's clothing? Journal of Poverty and Social Justice (21) 3, 247-257. https://doi.org/10.1332/20467431 3x13812372137921

Moore, Michael-Lee \& Westley, Francis R. \& Nicholls, Alex (2012) The Social Finance and Social Innovation Nexus. Journal of Social Entrepreneurship 3 (2), 115-132. https://doi.org/10.1080/1942 0676.2012.725824

Mosenson, Steven H. (2013) New models of private sector financing of not-forprofit corporations. Väitöskirja. Boston: Northeastern University. https://search. proquest.com/docview/1492326733/ fulltextPDF/A8D82936EE8F4E05PQ/ 1 ? accountid=11365 luettu 14.1.2018.

Mulgan, George \& Reeder, Neil \& Aylott, Mhairi \& Bo'sher, Luke (2011) Social Impact Investment: The Challenge and Opportunity of Social Impact Bonds. London: The Young Foundation. https://doi.org/10.1332/policypress/9781447340706.003.0004

Mäki, Kirsi (2012) Yhteiskunnallinen yritys, hae Hyvän työn -palkintoa. Sitra, uutiset: https://www.sitra.fi/uutiset/yhteiskunnallinen-yritys-hae-hyvan-tyonpalkintoa/ luettu 10.10.2018.

Männistö, Harri (2016) Vaikuttavuusinves- 
toimisen opas sijoittajille. Sitran selvityksiä 120. Helsinki: Sitra.

Mänttäri-van der Kuip, Maija (2013) Julkinen sosiaalityö markkinoistumisen armoilla?Yhteiskuntapolitiikka 78 (1), 5-19.

Nicholls, Alex \& Murdock, Alex (2012) The nature of social innovation. Teoksessa Alex Nicholls \& Alex Murdock (toim.) Social Innovation: Blurring Boundaries to Reconfigure Markets. London: Palgrave Macmillan, 1-32. https://doi. org/10.1007/s11266-013-9390-5

Nicholls, Alex (2013) Filling the capital gap. Teoksessa Simon Denny \& Frederic Seddon (toim.) Social Enterprise: Accountability and Evaluation around the World. Abingdon: Routledge, 161-195.

Nicholls, Alex \& Tomkinson, Emma (2013)

The Peterborough pilot social impact bond. http://eureka.sbs.ox.ac.uk/5929/ luettu 28.12.2017.

Niemelä, Mikko (2008) Julkisen sektorin reformin pitkä kaari Valtava-uudistuksesta Paras-hankkeeseen. Kelan tutkimusosasto. Helsinki: Kansaneläkelaitos.

Olson, John \& Phillips, Andrea (2013) Rikers Island:The first social impact bond in the United States. Community Development Investment Review 9, 97-101.

Palola, Elina \& Karjalainen, Vappu (toim.) (2011) Sosiaalipolitikka - Hukassa vai uuden jäljillä? Helsinki: Terveyden ja hyvinvoinnin laitos.

Peterson, Richard A. (2005) Problems in comparative research: The example of omnivorousness. Poetics 33 (5-6), 257-282. https://doi.org/10.1016/j. poetic.2005.10.002

Pikkarainen, Pentti (2017) Vaikuttavuusinvestoimisen ystävät palveluksessanne! Sitra, blogit. https://www.sitra.fi/blogit/ vaikuttavuusinvestoimisen-ystavat-palveluksessanne/ luettu 19.12.2017.

Powell, Martin \& Hewitt, Martin (2002) Welfare state and welfare change. Philadelphia, Pa: Open University Press.

Pyykkö, Mika \& Keltanen, Taru (2016) Mikä ihmeet työhyvinvointi-SIB? Kysymyksiä ja vastauksia. Helsinki: Sitra. https://doi.org/10.30666/elore.78662

Ritakallio, Veli-Matti (2007) Vauraudesta osattomaksi jääneet - köyhyys Suomessa 1995-2005. Teoksessa Heikki Taimio (toim.) Talouskasvun hedelmät - kuka sai ja kuka jäi ilman? Helsinki: Työväen Sivistysliitto TSL ry.

Rotheroe, Abigail \& Lomax, Plum \& Joy, Iona (2013) Allia's Future for Children Bond: Lessons Learned. London: New Philanthropy Capital.

Saari, Juho (2013) Julkinen talous ja sosiaalimenot. Teoksessa Tapio Raunio \& Juho Saari (toim.) Euroopan paras maa? Helsinki: Gaudeamus, 62-88.

Shiller, Robert J. (2013) Capitalism and financial innovation. Financial Analysts Journal 69 (1), 21-25. https://doi. org/10.2469/faj.v69.n1.4

Sinclair, Stephen \& McHugh, Neil \& Huckfield, Leslie \& Roy, Michael \& Donaldson Cam (2014) Social impact bonds: Shifting the boundaries of citizenship. Teoksessa Kecin Farnsworth, Zoë Irving \& Menno Fenger (toim.) Analysis and Debate in Social Policy. Social Policy Review 26. Bristol: Policy Press, 119-136. https://doi.org/10.1332/policypress/9781447315568.003.0007

Social Finance (2011) A Technical Guide to Developing a Social Impact Bond: Vulnerable Children and Young People. London: Social Finance. http://www. socialimpactexchange.org/sites/www. socialimpactexchange.org/files/publications/Technical_Guide_Vulnerable_ Children.pdf luettu 13.1.2018.

Social Investment Task Force (2010) Social investment ten years on. London: Social Investment Task Force. https://doi. org/10.18411/d-2016-154

Työ- ja elinkeinoministeriö (2016) Vaikuttavuusinvestointihanke - Maahanmuuttajien nopea työllistyminen. Muistio, liite 1, 7.6.2016. https://valtioneuvosto.fi/ delegate/file/16104 (luettu 11.10.2018)

Työ- ja elinkeinoministeriö (2017) Maahanmuuttajien työllistymistä nopeutetaan uusilla panostuksilla. Tiedote 2.6.2017. http://tem.fi/artikkeli/_/asset_publisher/maahanmuuttajien-tyollistymistanopeutetaan-uusilla-panostuksilla luettu 10.1.2018

Vaarama, Marja (2011) Prologi: Sosiaalipolitiikan nykytila.Teoksessa Elina Palola \& Vappu Karjalainen (toim.) Sosiaalipolitikka - Hukassa vai uuden jäljillä? Helsinki: Terveyden ja hyvinvoinnin laitos, 15-29. 
Van Gerven, Minna (2012) Sosiaalipolitiikan paradigman muutos: Työkyvyttömyyspolitiikan uudet kasvot Alankomaissa ja Suomessa.Yhteiskuntapolitiikka 77 (2), 134-144.

Warner, Mildred (2012) Profiting from Public Value? The Case of Social Impact Bonds, Draft Paper prepared for Creating Public Value Conference. Minneapolis: University of Minnesota. http://citeseerx.ist.psu.edu/viewdoc/download?doi $=10 \cdot 1 \cdot 1 \cdot 453.5341 \& \mathrm{rep}=$ rep $1 \&$ type $=$ pdf luettu 15.1.2018.

Warner, Mildred E. (2013) Private finance for public goods: Social impact bonds. Journal of Economic Policy Reform 16
(4), 303-319. https://doi.org/10.1080/1 7487870.2013 .835727

Wilson, Karen E. (2014) New Investment Approaches for Addressing Social and Economic Challenges. OECD Science, Technology and Industry Policy Papers 15. Paris: OECD Publishing. https://doi. org/10.1787/5jz2bz8g00jj-en

Yliaska, Ville (2014) Tehokkuuden toiveuni: Uuden julkisjohtamisen historia Suomessa 1970-luvulta 1990-luvulle. Helsinki: Into-Kustannus. 